\title{
Insertion and removal of a single implant contraceptive releasing 3-ketodesogestrel
}

\author{
Biran Affandi
}

\begin{abstract}
Abstrak
Implanon ${ }^{\bowtie}$ dikembangkan dengan tujuan untuk mendapatkan kontrasepsi implan dengan efektivitas dan penerimaan yang tinggi serta aman. Implanon ${ }^{\circledast}$ merupakan kontrasepsi implant generasi kedua. Terdiri dari satu batang etilin vinil asetat yang berisi etonogestrel atau 3-ketodesogestrel. Implanon ${ }^{\boxplus}$ disusukkan (insersi) subdermal di lengan atas bagian dalam dengan atau tanpa anestesia lokal. Implanon dikemas dalam inserter "disposable" yang steril. Untuk melakukan insersi yang baik dan benar, hal-hal berikut ini harus diperhatikan: pencegahan infeksi, insersi subdermal, dengan teknik yang betul. Waktu rata-rata insersi 1,2 menit. Pencabutan memerlukan waktu lebih lama. Bila Implanon ${ }^{\circledR}$ dipasang dengan baik, pencabutan tidak sulit. Pencabutan dilakukan dengan teknik "Pop-out" atau teknik standar. Waktu rata-rata pencabutan 5 menit. Langkah demi langkah pemasangan dan pencabutan Implanon ${ }^{\circledR}$ dipaparkan. Pelatihan pemasangan dan pencabutan harus diikuti oleh mereka yang akan memberikan pelayanan Implanon ${ }^{\circledR}$.
\end{abstract}

\begin{abstract}
With the objective to discover a single implantable contraceptive that highly effective, acceptable and safe a single ethylene vinyl acetate-rod containing 3-ketodesogestrel (Implanon $\left.{ }^{(}\right)$was developed. Implanon is a second-generation of implantable contraceptive. It is to be inserted subdermally into the inner side of the upper arm with or without using local anesthesia. Implanon ${ }^{\circledR}$ was delivered in the needle of a sterile, disposable, specially designed inserter, individually packed. In order to have a proper insertion one should pay special attention to: infection prevention, correct subdermal placement of the implant, and careful technique to minimize trauma. The average insertion time is 1.2 minutes. Removal take longer time than insertion. With pop-out technique or standard technique, removal will not be difficult provided the implant inserted properly. The average of removal time is 5.0 minutes. The step by step of insertion and removal procedures (practical guidelines) is described. In order to be competence in insertion and removal training is mandatory for doctors or midwives/nurses who wish to participate in Implanon services. This is the third paper of three papers reported on phase II study with a single implant containing 3-ketodesogestrel.
\end{abstract}

Keywords: Implanon ${ }^{\oplus}$, implant contraceptive, insertion and removal.

Research on contraceptive implants has already been initiated during the 1960 s by Croxatto and colleagues. ${ }^{1}$ A breakthrough was reached by 1978 when the Population Council demonstrated the feasibility of a new contraceptive implant system consisting of six levvonorgestrel-containing capsules for subdermal insertion (Norplant $\left.{ }^{\circledR}\right){ }^{2}$ Norplant $^{\circledR}$ was introduced in 1983 in Finland and subsequently in many other countries. After the introduction in the U.S.A. in 1991, its use increased rapidly with already about half a million American women using the method by 1994. Although perceived as an effective and acceptable method of contraception (both contraceptive ef-

Klinik Raden Saleh, Department of Obstetrics and Gynecology Faculty of Medicine, University of Indonesial Dr. Cipto Mangunkusumo National Hospital, Jakarta, Indonesia ficacy and continuation rates appeared to be superior to oral contraceptives), Norplant ${ }^{\circledR}$ lost popularity when reports appeared about the difficult removal of the implants.3,4 This was followed by legal action in the U.S.A. that drew attention of both the lay media and health action groups. The result was that the Norplant ${ }^{\circledR}$ prescription rate reduced sharply, mainly because of (a) reduced acceptance by women because of fear of side effects induced by a tangle and hostile press, and (b) reduced prescription rates by doctors because of fear of litigation. In order to improve insertion and removal of Norplant, emphasis was put on proper training of doctors and family planning nurses ${ }^{5}$ as well as on improved removal techniques. ${ }^{6}$

Another approach to prevention of the difficult insertion and removal of contraceptive implants would be by reducing the number of implants and/or by making them smaller and stiffer. Various innovative contraceptive implant systems using less rods are cur- 
rently under clinical development and one of these is Implanon. Implanon is an ethylene vinyl acetate (EVA) single-rod contraceptive implant containing etonogestrel (3-ketodesogestrel), the active metabolite of the widely used progestogen desogestrel. The objectives in the development of Implanon were to create (a) a single-rod system (to improve insertion and removal), (b) a release of etonogestrel (ENG) of at least $30 \mu \mathrm{g} / \mathrm{day}$ (the amount which is needed for complete inhibition of ovulation), (C) a duration of use of 2-3 years (to allow birth-spacing), and (d) an implant with a small diameter (to allow use of an injection system for insertion) $)^{7}$ Feasibility and pharmacological studies have indicated that all four objectives have been met, expressed by the convenient and fast insertion and removal procedures, and ENG release rate of $>30 \mu \mathrm{g} /$ day throughout the recommended duration of use and the induction of ovulation inhibition. 8,9

The objectives of this paper are:

1. Describe the step by step (practical guidelines) of the technique of insertion and removal.

2. To report the results of the insertion and removal technique described above.

\section{MATERIALS AND METHODS}

\section{Implant}

Implanon ${ }^{\circledR}$ is a single-rod implantable contraceptive with a length of $40 \mathrm{~mm}$ and a diameter of $2 \mathrm{~mm}$ containing approximately $68 \mathrm{mg}$ of etonogestrel (ENG), 3-ketodesogestrel. The rod is made of ethylene vinyl acetate (EVA) with an etonogestrel core surrounded by an EVA membrane. The initial release rate of etonogestrel from Implanon is approximately 67 $\mu \mathrm{g} /$ day.

Implanon ${ }^{\circledR}$ was delivered in the needle of a sterile, disposable, specially designed inserter individually packed in an aluminium sachet.

\section{Design of the study}

Two hundred women were recruited in the study. The inclusion criteria were age between 18 and 40 years, sexually active and of childbearing potential, good physical and mental health, normal cycles with a length of 24-35 days and a variation of $<3$ days, ability and willingness to accurately fill in the diary card with information on bleeding, accept the implant as the sole method of contraception, willing to return to the clinic at the stipulated time-points, and willing to give informed written consent.

The exclusion criteria were : pregnancy, breast feeding, within two weeks after an abortion, before the first menses after delivery, use of an injectable or implant hormonal method of contraception within a period of six months or the use of other hormonal contraceptives within a period of two months, history of ectopic pregnancy, past or present significant gynecological disorders of the uterus and/or the ovaries, uncontrolled significant endocrine disorder, haemoglobin $(\mathrm{Hb})$ less than $10 \mathrm{~g} / \mathrm{dl}$, breast discharge (other than lactation), past or present disturbance of liver function i.e. cholestatic jaundice, a history of jaundice of pregnancy or jaundice due to previous (oral) contraceptive use, Rotor syndrome or Dubin Johnson syndrome, history of hyperlipoproteinaemia, hypertension i.e. systolic BP $>140 \mathrm{mmHg}$ and/or diastolic $\mathrm{BP}>90 \mathrm{mmHg}$, use of one or more of the following drugs : sex steroids, hydantoins, barbiturates, primidone, carbamazepine, rifampicin and griseofulvin, a history of (within 12 months) alcohol or drug abuse, and administration of investigational drugs within 3 months prior to this study.

\section{Characteristics of implant}

Implanon is a single-rod implant with a length of 40 $\mathrm{mm}$ and a diameter of $2 \mathrm{~mm}$ containing approximately $68 \mathrm{mg}$. The rod is made of EVA with an ENG surrounded by and EVA membrane. The initial release rate of ENG from Implanon is approximately $67 \mu \mathrm{g} / \mathrm{day}$.

Implanon ${ }^{\circledR}$ was delivered in the needle of a sterile, disposable, specially designed inserter individually packed in an aluminium sachet. The sachets were labelled with the protocol number, storage conditions, information on content of sachet, expiry date, packing number and the subject number.

If a subject met all entry criteria and a written informed consent form was signed, screening assessment were to be done. Results of these assessment had to be available before implantation.

The experimental flow of the study after completion of the screening assessment is demonstrated in Table 1. The implant was to remain in situ for 24,36 or 48 months, depending on the willingness of the volun- 
teers to give their consent to the extension of the study. Assessments were scheduled at 3-month intervals during the study. To allow some flexibility to the subjects, a 1-month deviation was allowed. During the whole study period occurrence of adverse experiences as well as use of concomitant medication were to be reported. If suspected at any time in the study, a pregnancy test was to be performed. Data on the subject's bleeding pattern were to be recorded by the subject on a daily basis in a diary card.

\section{Profile of the subjects}

The profile of the subjects are described in Table 1. Age ranged from 20 to 35 years old with mean 28.3 years (SD 3.7).

Table 1. Profile of subjects $(\mathrm{N}=200)$

\begin{tabular}{|c|c|c|c|}
\hline \multicolumn{2}{|l|}{ Profile } & Mean $\pm S D$ & $\%$ \\
\hline \multicolumn{2}{|l|}{ Age (years) } & $28.3 \pm 3.7$ & \\
\hline \multicolumn{2}{|l|}{ Height $(\mathrm{cm})$} & $154.0 \pm 4.7$ & \\
\hline \multicolumn{2}{|l|}{ Body Weight (kg) } & $49.8 \pm 8.1$ & \\
\hline \multicolumn{2}{|c|}{ Body Mass Index $(\mathrm{kg} / \mathrm{cm} 2)$} & $21.0 \pm 3.0$ & \\
\hline \multicolumn{2}{|c|}{ Parity : $1-2$} & 12.1 & 60.5 \\
\hline \multicolumn{2}{|l|}{$3-$} & 79 & 39.5 \\
\hline \multirow{6}{*}{ Last Contraception : } & - None & 60 & 30.0 \\
\hline & - Pill & 3 & 1.5 \\
\hline & - Implantables & 2 & 1.0 \\
\hline & - Injectables & 2 & 1.0 \\
\hline & - IUD & 131 & 65.5 \\
\hline & - Others & 2 & 1.0 \\
\hline
\end{tabular}

The mean body weight was $49.8 \pm 8.1 \mathrm{~kg}$, while the mean height was $154.0 \pm 4.7 \mathrm{~cm}$, making the mean Body Mass Index $21.0 \pm 3.0 \mathrm{~kg} / \mathrm{cm}^{2}$. All the subjects have already experienced at least one delivery para 3 or above. With regard to last contraceptive method use being $65,5 \%$ IUD and $30 \%$ of them had used no method at all.

\section{Technique of insertion}

The implant must be placed beneath an area of healthy skin on the inner aspect of the upper arm. Use the arm that the woman uses less.

First, wash the skin with soap and water, then swab with antiseptic. The implant is introduced by a specially designed disposable inserter.

The implant is fed through the inserter and placed just beneath skin. Sutures are not required; a simple bandage is enough.
It is important that the implant be placed superficially just beneath the skin (dermis). Deep placement will make removal much more difficult.

\section{Steps in insertion}

1. The client should wash her arm thoroughly with soap and water. The client may lie down horizontally on the table and her left arm (right arm is used if patient is left handed) is placed on a support or she may sit on a chair and her arm is placed on a table. The left arm should be comfortable extended straight or slightly bent.

2. Identify the insertion site. This could be inside the upper arm about $6-8 \mathrm{~cm}$ above the fold of the elbow.

3. With or without wearing sterile gloves, apply the antiseptic solution.

4. Pick up the disposable package which contains a sterile disposable inserter with an Implanon-rod in it.

5. Remove the sterile disposable inserter from the package.

6. Ramove the cap of introduce needle under the skin of inner side of the upper arm, up to the syringe. During insertion the needle should be tilted upward, tenting the skin, to keep the implant in superficial plane. Do not force the needle and if resistance is felt, try another angle.

7. Break seal by turning long plunger support while faxing the inserter with the other hand.

8. Turn the plunger 180 degrees.

9. Keep plunger fixed by pressing small plunger support downward and pull inserter backwards by which the implant is released from the needle.

10. The inserter is thrown away.

\section{Technique of removal}

An easy removal depends on correct insertion. Routine removals take longer than insertions-usually from 2-5 minutes.

It is helpful to locate the implant first with ungloved fingers. Some clinicians mark the positions of implant with a pen. The area is washed with soap and water and then swabbed with antiseptic solution before a local anesthetic is applied to the incision site. The clinician should apply the anesthetic under the end of the implant; anesthetic applied over the cap- 
sules may obscure them.

Only one small incision should be made, through which the implant is removed. The incision should be no longer than $3 \mathrm{~mm}$.

If the implant prove difficult to remove, heroic measures should not be taken to remove them. Total time for removal should not exceed 5-10 minutes. In this situation, the woman should be asked to return when the area is fully healed (about 4-6 weeks) and a second attempt made. Hard-to-find implant can be located through $x$-rays or by ultrasound. Finally, the clinician should work gently and carefully to avoid injuring the client's arm.

\section{Steps in removal}

The position of the client and the infection prevention procedure are the same as for insertion.

1. Palpate the implant and mark its position. After prepping and draping the area, apply local anesthetic under the proximal end of the implant.

2. With a scalpel make a $3 \mathrm{~mm}$ incision at the end of the implant.

3. Push the implant gently towards the incision with the fingers.

4. When the tip of the implant is seen by using a scalpel dissect the fibrous tissue at the end of the implant to open the fibrous capsule. By poping out the implant is expeled.

5. Or grasp the implant by a Mosquito forcep and than clean the fibrous tissue using a scalpel or a gauze.

6. After the implant has been removed the incision is closed and bandaged.

Client instructions and follow-up.

\section{Wound care}

Keep the area dry and clean for at least 48 hours. The incision could become infected if the area gets dirty, wet while bathing or washing clothes.

There may be bruising, swelling or tenderness at the insertion site for a few days. This is normal.

Routine work can be done immediately, but do not put unusual pressure on the area for a few days. After the incision has healed, the woman may touch the skin over the implant. The soft, flexible implant can- not break inside the body, so she should not be concerned about putting normal pressure on the area.

Leave the gauze pressure bandage in place for 48 hours and the bandaid or surgical tape in place until the incision heals (3-5 days).

If signs of infection occur, such as fever, inflammation (redness with heat) at the site, or if there is persistent pain for several days, return to the clinic.

\section{RESULTS}

\section{Insertion}

Table 2. Insertion time

\begin{tabular}{lrrrr}
\hline & N & $\%$ & \multicolumn{2}{c}{ Time } \\
& & & Range & Mean \pm SD \\
\hline With local anaesthesia & 89 & 44.5 & $0.05-4.5$ & $0.7 \pm 0.5$ \\
Without local anaesthesia & 111 & 55.5 & $0.03-3.0$ & $0.5 \pm 0.2$ \\
\hline
\end{tabular}

$p<0.01$

In the beginning the implanon was inserted using local anaesthesia. Approximately $1 \mathrm{ml}$ xylocaine $1 \%$ was injected prior to Implanon insertion.

Since the injection of anaesthesia itself caused some pain, it was decided not to use anaesthesia started with the subject number 90 .

The insertion time is described in Table 2. The mean insertion time with local anaesthesia is $0.7 \pm 0.5 \mathrm{~min}$ utes. The mean insertion time without local anaesthesia is $0.5 \pm 0.2$ minutes. The difference is statistically significant.

Table 3. Condition of implant site

\begin{tabular}{lrrrr}
\hline \multirow{2}{*}{ Condition } & \multicolumn{4}{c}{ Time after insertion } \\
& $\mathrm{N}$ & $\%$ & $\mathrm{~N}$ & $\%$ \\
\hline Swelling & 0 & 0.0 & 0 & 0.0 \\
Redness & 5 & 2.5 & 0 & 0.0 \\
Haematoma & 3 & 1.5 & 0 & 0.0 \\
Pain & 15 & 2.5 & 1 & 0.5 \\
Expulsion & 0 & 0.0 & 0 & 0.0 \\
No Abnormalities & 177 & 93.5 & 199 & 99.5 \\
\hline Total & 200 & 100.0 & 200 & 100.0 \\
\hline
\end{tabular}


Pain, redness and haematoma were the main complaint and condition among Implant users, one week after insertion. After one year, only one subject complaint about pain.

\section{Removal}

Table 4. Removal

\begin{tabular}{crr}
\hline Time (minutes) & N & $\%$ \\
\hline-1.9 & 111 & 70.7 \\
$2.0-4.9$ & 30 & 19.1 \\
$5.0-9.9$ & 10 & 6.4 \\
$10.0-15.0$ & 6 & 3.8 \\
\hline Total & 157 & 100.0 \\
\hline \multirow{2}{*}{ Mean \pm SD } & \multicolumn{2}{c}{$2.1 \pm 7.7$} \\
\hline
\end{tabular}

The mean removal time was $2.1 \pm 7.65$ minutes with the range between $0.2-15.0$ minutes.

\section{DISCUSSION}

This is the third paper of three papers reported the results of Phase II Study with a single implant contraceptive releasing 3-ketodesogestrel.

It is estimated there are at least 3 million women from all over the world using Norplant ${ }^{\circledR}$ as their contraceptive method.12 However, despite apparent popularity, Norplant ${ }^{\circledR}$ has several disadvantages. One of the main disadvantages is insertion and removal of 6 capsules. It must have been easier if the implant consist of 1 rod. The insertion time of Implanon ${ }^{\circledR}$ is $0.7 \pm 0.5$ minutes and the removal time is $2.1 \pm 7.65$ minutes which is much less compared to insertion and removal time of Norplant ${ }^{\circledR}$ being 7.4 minutes and 21.8 minutes.

In order to help the providers learn the steps or tasks involved in implanon services, three learning guides have been developed:

- Learning Guide for Implanon ${ }^{\circledR}$ Counseling Skills

- Learning Guide for Implanon ${ }^{\circledR}$ Clinical Skills: Insertion

- Learning Guide for Implanon ${ }^{\circledR}$ Clinical Skills : Removal
Learning guide for Implanon ${ }^{\circledR}$ counseling skills

\section{Objectives}

\section{Task/activity}

\section{Counseling (insertion)}

\section{Initial interview (client reception area)}

1. Greet woman respectfully and with kindness

2. Establish purpose of the visit and answer questions

3. Provide general information about family planning

4. Give the woman information about the contraceptive choices available and the risks and benefits for each:

- Show where and how Implanon ${ }^{\circledR}$ for each

- Explain how they works and their effectiveness

- Explain possible side effects and other health problems

- Explain benign nature of the common side effects

5. Explain what to expect during the clinic visit

\section{Method-specific counseling (counseling area)}

1. Assure necessary privacy

2. Obtain biographic information (name, address, etc)

3. Ask the client about her reproductive goals. (Does she want to differ or space or limits births?)

4. Explore any attitudes or religious beliefs that either favor or rule out one or more methods

5. Discuss client's needs, concerns and fears in a through and sympathetic manner

6. Help client begin to chose an appropriate method

\section{If she chooses Implanon ${ }^{(1)}$}

1. Screen client carefully to make sure there is no medical condition that would be a problem (complete Client Screening Checklist)

2. Explain potential side effects and make sure that each is fully understood

\section{Pre-insertion counseling (procedure/examination area)}

1. Review Client Screening Checklist to determine if client is an appropriate candidate for Implanon ${ }^{\circledR}$ and if she has any problems that should be monitored while Implanon ${ }^{(B)}$ are place 
2. Check that client is within seven (7) days of onset of menstrual period

3. Check for pregnancy if beyond day 7. (Non-medical) counselors must refer client for further evaluation)

4. Perform further evaluation (physical examination), if indicated. (Non-medical counselor must refer client for further evaluation)

5. Describe the insertion process and what the woman should expect during and afterwards

\section{Postinsertion counseling}

1. Complete client record including drawing position of implant

2. Discuss what to do if the client experiences any side effects of problems

3. Provide followup visit instruction

4. Remind client of 3-year effective life of Implanon $^{\circledR}$

5. Assure client she can return to the same clinic at any time to receive advice or medical attention and, if desired, to have the implant removed.

6. Ask the client to repeat instructions

7. Answer client questions

8. Observe client for at least 15 minutes before sending home.

\section{Counseling (removal)}

\section{Pre-removal counseling (client reception area)}

1. Greet woman respectfully and with kindness

2. Establish purpose of visit

\section{Method-specific counseling (counseling area)}

1. Ask client her reason for removal and answer any questions

2. Ask client about her present reproductive goals. (Does she want to continue differing or spacing or limiting births?)

3. Describe the removal process and what she should expect during the removal and afterwards

\section{Postremoval counseling}

1. Instruct client regarding wound care and make return visit appointment, if needed

2. Discuss what to do if client experiences any problems (e.g. fever)

3. Ask client to repeat instructions

4. Answer any questions
5. Review general and method-specific information about family planning methods if client wants to continue differing or spacing or limiting births

6. Assist client in obtaining new contraceptive method or provide temporary method (barrier) until method of choice can be started

7. Observe client for at least 15 minutes before sending home

\section{Learning guide for implanon insertion}

\section{Getting ready}

1. Determine that client has been counseled for insertion procedure

2. Review client screening checklist and further evaluate client, if indicated

3. Check to be sure client has thoroughly washed her entire arm

4. Help position client onto table

5. Select and position woman's arm and place clean, dry cloth under her arm

6. Determine insertion area by measuring $8 \mathrm{~cm}$ above the elbow fold

7. Determine that sterile Implanon ${ }^{\circledR}$ package is present

\section{Pre-insertion tasks}

1. Wash hands thoroughly with soap and water and dry with clean, dry cloth

2. Prepare injection/insertion site by applying antiseptic solution to area

\section{Insertion}

1. Remove sterile disposable inserter from pouch

2. Inject insertor at a shallow angle (While tenting the skin)

3. While tenting the skin, slowly and smoothly advance insertor to the upper end of the needle

4. Break seal by turning long plunger support while fixing the inserter with the other hand

5. Turn plunger $180^{\circ}$ degrees

6. Withdraw inserter while fixing plunger with left hand. The implant is released from the needle

7. Palpate implant to check that implant has been inserted properly

\section{Post-insertion tasks}

1. Press down on injection site with gauze finger to stop bleeding

2. Close it with bandaid or surgical tape 
3. Apply pressure dressing to injection site and wrap gauze bandage snugly around the arm to ensure hemostasis and minimize bruising

4. Advise client to return to clinic if pus, blood or implant comes out of injection site

5. Fill syringe (with needle attached) with $0,5 \%$ chlorine solution and soak for 10 minutes. Dispose of needle and syringe by placing in puncture-proof container

6. Dispose of waste materials according to guidelines

7. Wash hands thoroughly with soap and water and dry with clean, dry cloth

8. Draw location of implant in the client record and note anything unusual

9. Observe client for at least $\mathbf{1 5}$ minutes before sending her home

\section{Learning guide for Implanon ${ }^{\circledR}$ removal}

\section{Getting ready}

1. Ask client her reason for removal

2. Ask client if she understands removal procedure

3. Ask client about allergies to anesthetic agent

4. Check to be sure client has thoroughly washed her entire arm

5. Help position client on to table

6. Select and position woman's arm and place clean, dry cloth under her arm

7. Palpate implant to locate point for removal incision

8. Determine that required sterile or high-level disinfected instruments are present

9. Open sterile instrument pack

\section{Pre-removal tasks}

1. Wash hands thoroughly with soap and water and dry with clean, dry cloth

2. Put sterile or high-level disinfected gloves on both hands; if gloves are powdered, wipe powdered, wipe powder off glove fingers with gauze soaked in sterile or boiled water

3. Arrange instruments and supplies

4. Prepare removal site by applying antiseptic solution to area, beginning at incision site and moving outward in a circular motion for 8 to $13 \mathrm{~cm}$; allow to air dry

5. Place sterile or high-level disinfected surgical drape over arm (optional)
6. Inject local anesthetic (1\% without epinephrine) at the incision site under the end of the implant

7. Check for anesthetic effect before making incision

\section{Removal: standard technique}

1. Make small ( $4 \mathrm{~mm})$ incision with scalpel about 5 $\mathrm{mm}$ below the tip of implant nearest the elbow

2. Gently push implant towards the incision until tip is visible (if possible)

3. Grasp and of implant with curved (mosquito or Crile) forceps and gently bring it into the incision

4. Clean off and open fibrous sheath surrounding implant with sterile gauze (or scalpel)

5. Grasp exposed implant with second forceps and release first forceps

6. Slowly and gently remove implant and place it in a bowl containing $0.5 \%$ chlorine solution

7. Inject more anesthetic if required

\section{Removal: 'U' technique}

1. Make a small ( $4 \mathrm{~mm})$ skin incision vertically over the implant above the tip nearest the elbow fold

2. Insert tip of Implant-holding (or no-scalpel vasectomy-holding) forceps and, while stabilizing rod, advance tip of forceps until it touches the implant

3. Grasp implant at right angles and gently pull rod into the incision (flip handles $180^{\circ}$ if necessary)

4. Clean off and open fibrous tissues sheath with sterile gauze (or scalpel) if needed

5. Grasp exposed end of implant with curved forceps, remove implant and place in bowl containing $0.5 \%$ chlorine solution

\section{Removal: pop-out technique}

1. Push on proximal end of implant with a finger

2. When the distal tip pushes up under the skin, make a small ( 2 to $3 \mathrm{~mm}$ ) incision over the tip with the scalpel

3. Squeeze the tip between the thumb and finger so that it pushes up into the incision

4. Insert the scalpel blade into the incision until it just touches the tip of the implant and if necessary cut the fibrous tissue surrounding the tip of the rod

5. With the sheath opened, gently squeeze the tissue surrounding the tip of the implant with both thumbs to bring the tip into view 
6. Apply gently pressure on the proximal end of the implant to make it "pop out" of the incision

7. Place implant in bowl containing $0.5 \%$ chlorine solution

\section{Post-removal tasks}

1. After removal of implant show it to client

2. Close the incision with bandaid or surgical tape

3. Apply pressure dressing to removal area and wrap gauze bandage snugly around the arm to ensure hemostasis and minimize bruising

4. Instruct client regarding wound care. Advise client to return to clinic if pus or blood come out of removal site

5. Fill syringe (with needle attached) with $0,5 \%$ chlorine solution and soak for 10 minutes. Dispose of needle and syringe by placing in a puncture-proof container. Alternatively, process syringe for reuse and dispose of needle

6. Place intruments in $0,5 \%$ chlorine solution and soak for 10 minutes

7. Dispose of waste materials and Implanon ${ }^{\circledR}$ according to guidelines

8. Briefly immerse gloved hands in chlorine solution. If disposing of gloves, place in leak-proof container or plastic bag. If reusing gloves, soak gloves in $0,5 \%$ chlorine solution for 10 minutes

9. Wash hands thoroughly with soap and water and dry with clean, dry cloth

10. Observe client for at least 15 minutes before sending her home

\section{Acknowledgement}

This study was conducted as part of Implanon ${ }^{\circledR} \mathrm{Re}-$ search and Development Program sponsored and coordinated by NV Organon, Oss, the Netherlands.

Thanks are due to Dr. Stevenson from N.V. Organon Holland for Good Clinical Practice Monitoring, to Drs. Wardojo Gadroen, Bandar Damanik and Susilo from Organon Indonesia for study coordination, to Dra. Rosminah from Klinik Raden Saleh for subjects coordination, to Drs. AGM Theeuwes and RMV Stoleman from SOG NV Organon for data analysis and to Ms Ernie for typing the manuscript.

\section{REFERENCES}

1. Croxatto H, Diaz S, Vera R, Etchart M, Atria P. Fertility control in women with progestogen released in microquantities from subcutaneous silastic capsules. Am J Obstet Gynecol 1969; 105: 1135-8

2. Coutinho E, da Silva AR, Mattos CE, Nielsen NC, Osler M, Wiese J. Contraception with long-acting subdermal implants: I. An effective and acceptable modality in international clinical trials. Contraception 1978; 18: 315-33.

3. Hatasaka H. Implantable levonorgestrel contraception: 4 years of experience with Norplant ${ }^{\boxplus}$. Clin Obstet Gynecol 1995; 38: 859-71.

4. Oloto E, Bromham D. Norplant ${ }^{\circledR}$ removal: a review. Br J Fam Plann 1995; 21(Suppl): 21-4.

5. Bromham D, Davey A, Gaffikin L, Ajello C. Materials, methods, and the results of the Norplant training program. Adv Contracept 1995; 11: 255-62.

6. Rosenberg MJ, Alvarez F, Barone MA, Waugh MS, Brache $\mathrm{V}$, Pollack AE. A comparison of " $U$ " and standard techniques for Norplant removal. Obstet Gynecol 1997; 89: 168-73.

7. Vemer HM, Bergink EW. Implanon: a promise for the future. In: Moeloek FA, Affandi B, Trounson AO, eds. Advances in Human Reproduction. New York: Parthenon 1995; $131-2$.

8. Diaz S, Pavez M, Moo-Young, Bardin CW, Croxatto HB. Clinical trial with 3-ketodesogestrel subdermal implants. Contraception 1991; 44: 393-408.

9. Davies G, Li XF, Newton JR, Beek A van, Coelingh Bennink HJT. Release characteristics, ovarian activity and menstrual bleeding pattern with a single contraceptive implant releasing 3-ketodesogestrel. Contraception 1993; 47: 251-61.

10. Darney PD. Hormonal Implants: Contraception for a New Century. Am J Obstet Gynecol 1994; 170: 1536-43.

11. Affandi B, Prihartono J, Lubis S et al. Insertion and Removal of Norplant $\left.{ }^{(}\right)$by Physicians and Nonphysicians. Studies in Family Planning 1997; 18: 302-6.

12. Affandi B. Manual on Implanon ${ }^{\circledR}$ for Providers. Organon Indonesia, Jakarta, 1997

13. Organon. Implanon ${ }^{\circledR}, 68 \mathrm{mg}$ etonogestrel, single rod implant. Scientific Information, 1997.

14. Mc Intosh N , Riseborough P, Davis C. Norplant ${ }^{\circledR}$ Guidelines For Family Planning Service Programs, A Problem Solving Reference Manual. JHPIEGO Corporation, Baltimore, Maryland, USA, 1996.

15. Darney PD. Hormonal Implants: Contraception for a New Century. A Comprehensive review of implant development, current knowledge, and future development. Am Obstet Gynecol 1994; 170: 1536-43. 